\title{
Lachancea thermotolerans Applications in Wine Technology
}

\author{
Antonio Morata ${ }^{1, *(1)}$, Iris Loira ${ }^{1}$ (D), Wendu Tesfaye ${ }^{1}$, María Antonia Bañuelos ${ }^{2}$, \\ Carmen González ${ }^{1}$ and José Antonio Suárez Lepe ${ }^{1}$ \\ 1 Department of Chemistry and Food Technology, ETSIAAB, Technical University of Madrid, \\ 28040 Madrid, Spain; iris.loira@upm.es (I.L.); wendu.tesfaye@upm.es (W.T.); \\ carmen.gchamorro@upm.es (C.G.); joseantonio.suarez.lepe@upm.es (J.A.S.L.) \\ 2 Department of Biotechnology-Plant Biology, ETSIAAB, Technical University of Madrid, \\ 28040 Madrid, Spain; mantonia.banuelos@upm.es \\ * Correspondence: antonio.morata@upm.es
}

Received: 20 June 2018; Accepted: 6 July 2018; Published: 11 July 2018

\begin{abstract}
Lachancea (kluyveromyces) thermotolerans is a ubiquitous yeast that can be naturally found in grapes but also in other habitats as soil, insects and plants, extensively distributed around the world. In a 3-day culture, it shows spherical to ellipsoidal morphology appearing in single, paired cells or short clusters. It is a teleomorph yeast with 1-4 spherical ascospores and it is characterized by a low production of volatile acidity that helps to control global acetic acid levels in mixed or sequential inoculations with either S. cerevisiae or other non-Saccharomyces species. It has a medium fermentative power, so it must be used in sequential or mixed inoculations with $S$. cerevisiae to get dry wines. It shows a high production of lactic acid able to affect strongly wine $\mathrm{pH}$, sometimes decreasing wine $\mathrm{pH}$ by 0.5 units or more during fermentation. Most of the acidification is produced at the beginning of fermentation facilitating the effect in sequential fermentations because it is more competitive at low alcoholic degree. This application is especially useful in warm areas affected by climatic change. $\mathrm{pH}$ reduction is produced in a natural way during fermentation and prevents the addition of tartaric acid, that produces tartrate precipitations, or the use of cation exchangers resins highly efficient reducing $\mathrm{pH}$ but with undesirable effects on wine quality. Production of lactic acid is done from sugars thus reducing slightly the alcoholic degree, especially in strains with high production of lactic acid. Also, an improvement in the production of 2-phenylethanol and glycerol has been described.
\end{abstract}

Keywords: Lachancea thermotolerans; Kluyveromyces thermotolerans; acidification; wines; sequential fermentations; non-Saccharomyces

\section{Introduction}

Lachancea thermotolerans was formerly known as Kluyveromyces thermotolerans, but it was recently reassigned in the genera Lachancea according to multigene sequence analysis [1]. L. thermotolerans (LT) is a global yeast species that can be usually found in grapes but also in other habitats as soil, insects and plants [2] and extensively distributed around the world [3]. It can be found in natural spontaneous wine fermentations with a low prevalence on days $2-4$ of fermentation [4]. Morphologically, it is globous or ellipsoidal, undistinguishable from S. cerevisiae (Figure 1) and can be found as single cells in liquid media or in small groups. It is a teleomorph yeast presenting sexual reproduction with the formation of spherical ascospores (1-4). Asexual reproduction is produced with multilateral budding. LT forms creamy colonies with butyrous texture in solid media.

LT is able to ferment glucose and sucrose [5] and weakly galactose. It shows variable capacity to ferment maltose, trehalose and raffinose [6]. Nitrogen nutrition is similar to S. cerevisiae being 
necessary a minimum of $200 \mathrm{mg} / \mathrm{L}$ of YAN (yeast assimilable nitrogen) to avoid sluggish or stuck fermentations [7]. Serine as N-source also has shown an improvement in the fermentation performance of LT [8]. Strains of LT can express the following extracellular enzymatic activities with effect in wine aroma or phenol extraction: Esterase, Esterase-Lipase, ß-glucosidase, Pectinase, Cellulase, Xylanase, Glucanase [9].
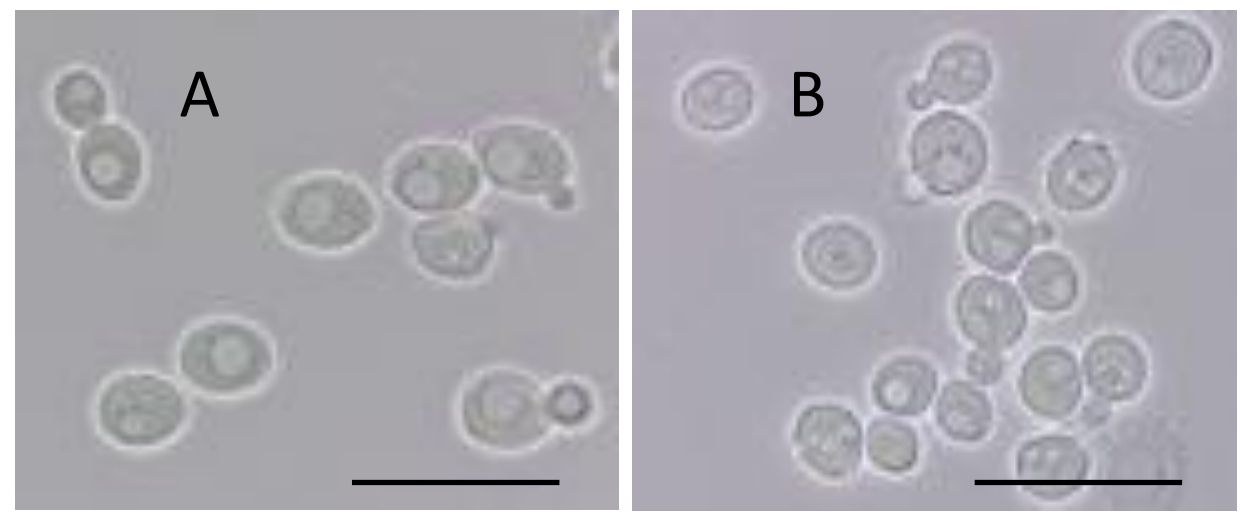

Figure 1. Optical microscopy (A) Saccharomyces cerevisiae (B) Lachancea thermotolerans. Scale $10 \mu \mathrm{m}$.

LT has a moderate fermentative power, and an ethanol tolerance around $5-9 \% v / v$ has been published [10-14]. Some effect can be observed in the reduction of the alcoholic degree of wines $(0.7 \% v / v ;[15])$. Concerning resistance in the time, it was observed that it is able to survive several days in the presence of $9 \% v / v$ of ethanol [11,16], and it also has a good persistence even when the fermentation is dominated by S. cerevisiae [17]. These metabolic properties make it appear during the intermediate phase of the fermentative process before the full prevalence of high fermentative S. cerevisiae strains. The use of LT in sequential or mixed fermentations has some tendency to produce sluggish fermentations with more difficulties fermenting the fructose fraction of the grape sugars [7]. Moreover, an oxygen availability requirement for LT persistence seems to be higher than for $S$. cerevisiae [18]. The tolerance to temperature is similar to average strains of $S$. cerevisiae showing a good growth at $25-30{ }^{\circ} \mathrm{C}$, but slower growth below $20{ }^{\circ} \mathrm{C}$ [5].

Comitini et al. [12] identified 5 isolates that are able to resist $10-20 \mathrm{mg} / \mathrm{L}$ of free $\mathrm{SO}_{2}$, but it is possible to find strains resistant to more than $100 \mathrm{mg} / \mathrm{L}$ of total $\mathrm{SO}_{2}$ [14]. The production of $\mathrm{H}_{2} \mathrm{~S}$ is variable from medium to high (25 isolates). Comitini et al. [12] also observed in 5 strains of LT a production of $\mathrm{SH}_{2}$ ranging from 3-5 in a 0-5 scale. Resistance to DMDC is low, from 25 to $100 \mathrm{mg} / \mathrm{L}$ for populations ranging $\log 2-\log 6 \mathrm{CFU} / \mathrm{mL}$, while typical values for S. cerevisiae are 100-300 mg/L with same population [19].

LT has been produced at the commercial level as dry yeasts since 2012 (CONCERTO $^{\mathrm{TM}}$ and MELODY ${ }^{\mathrm{TM}}$ ) and recommended to increase flavor complexity and intensity, to improve total acidity and to reduce volatile acidity [20,21]. It is well established that LT is capable of producing wines with higher 'spicy' and acidic notes, thus improving the overall quality of wine [13,22]. It is also described as producer of ethyl isobutyrate (strawberry nuances). Improvements in fruitiness, probably favored by the increase in acidity, are typical sensory descriptors when LT is used to ferment neutral varieties [23].

Some LT strains have been used as fungal biocontrol agents in grapes and vines to inhibit the growth of Aspergillus [24]. These strains do not affect the metabolic properties and performance of S. cerevisiae during alcoholic fermentation [25].

\section{Isolation and Selection}

As most of other non-Saccharomyces yeasts, LT can be distinguished from S. cerevisiae using lysine media (Figure 2; [26] and culturing temperatures in the range $25-28^{\circ} \mathrm{C}$. The use of chromogenic media is quite useful (Figure 2) for the initial isolation of yeasts belonging to this species. In CHROMagar ${ }^{\circledR}$ 
they show a characteristic red-brown color that can be distinguished easily from the purple colonies of Saccharomyces or the creamy colors of most of the other yeasts.

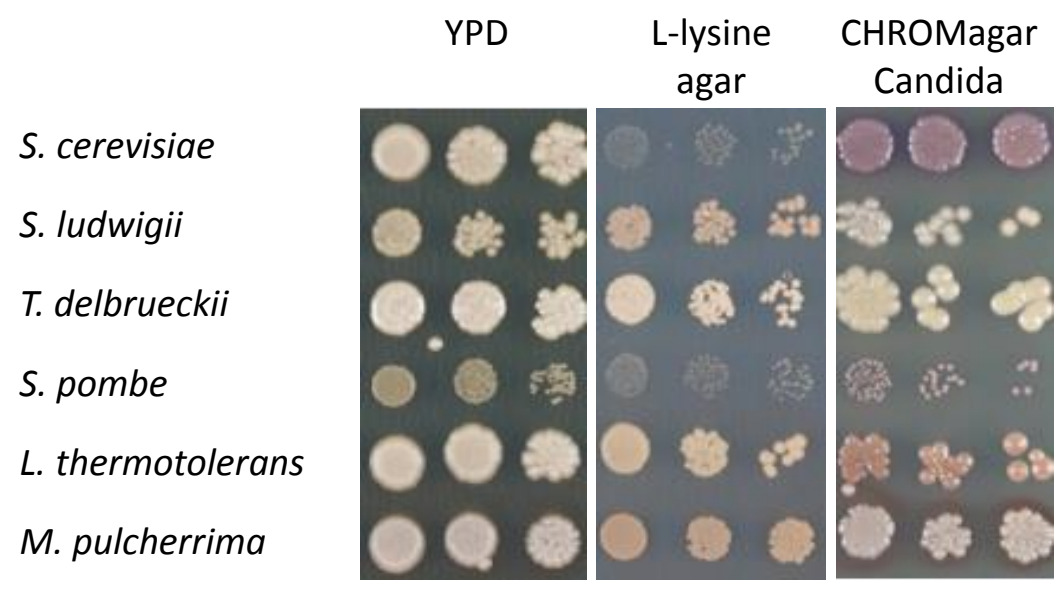

Figure 2. Colony shape and color in YPD, L-lysine specific to isolate non-Saccharomyces and Chromogenic media (Adapted from Loira et al. [26]).

The use of PCR-denaturing gradient gel electrophoresis (PCR-DGGE) has been proposed to identify LT during the study of the ecology of wine grapes, but with a low sensibility, needing a population of at least $\log 2 \mathrm{CFU} / \mathrm{mL}$ [27]. Microsatellite markers and a multilocus SSR analysis have been developed to assess the genetic diversity of LT isolates [28]. Identification of LT isolates can be performed by sequencing of the D1/D2 region of the 26S rRNA gene and RAPD fingerprinting what allows yeast identification at species level [29,30]. Moreover, restriction patterns of amplified regions of $26 \mathrm{~S}$ rDNA can be used as a routine methodology to identify non-Saccharomyces yeast species during red wine fermentation [31] (Figure 3). Finally, specific PCR primer pairs for the intron 2 of the mitochondrial COX1 gene, allow detect $L$. thermotolerans in wine at $10^{4}$ cells $/ \mathrm{mL}$ and with a S. cerevisiae/L. termotholerans ratio of 1000/1 [32].

A

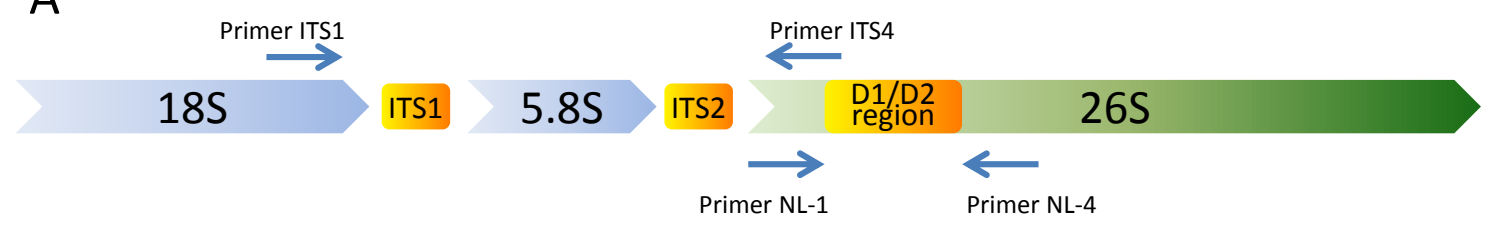

B

Internal Transcribed Spacer (ITS1)

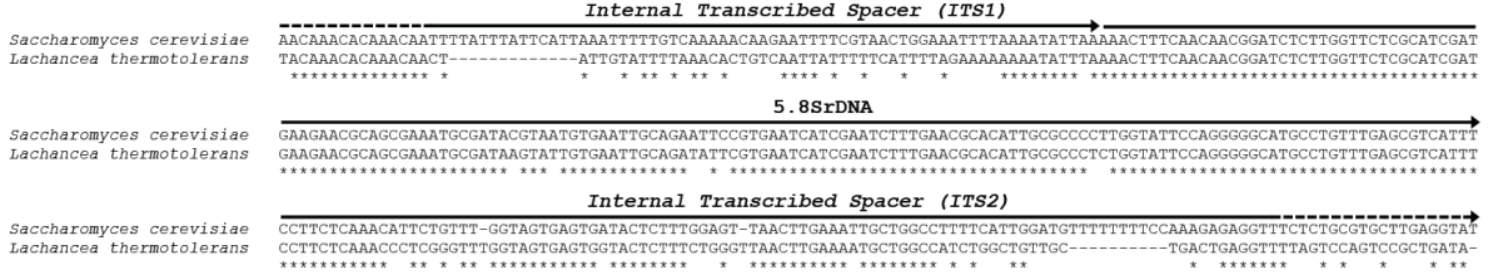

Figure 3. (A) Schematic diagram of the yeast rDNA gene cluster. The 18S, $5.8 \mathrm{~S}$ and 25-28S rDNA genes are separated by the internal transcribed spacers 1 (ITS1) and 2 (ITS2). Primers for routine sequencing are shown; (B) Alignments of complete 5.8S rDNA sequence and partial sequences of Internal Transcribed Spacer 1 and 2. The marked sequences are identical regions. GenBank accession numbers: for S. cerevisiae, KT958553.1 and for L. thermotolerans, CU928180.1. 


\section{Biotechnological Application: Wine Acidification}

Selected LT strains have been used for acidification of fermented beverages as wines $[13,33,34]$ and beers [35-37]. LT is a strong producer of lactic acid [33] with significant influence in wine $\mathrm{pH}$, also in other fermented beverages (Table 1). Lactic acid is stable after fermentation and ageing because it is neither chemically degraded nor microbiologically metabolized under enological conditions. Concentrations can range 1-16.8 g/L [28]. Most of the acidification is produced at the beginning of fermentation (Figure 4A), which facilitates the acidification in sequential fermentations with S. cerevisiae at low-medium ethanol levels $(<6 \% v / v)$ when LT is competitive with $S$. cerevisiae. The acidification strongly influences $\mathrm{pH}$ being possible to reduce more than $0.5 \mathrm{pH}$ units from an initial $\mathrm{pH}$ of 3.8-4 (Figure 4B). This has interesting implications in wines of warm areas because at $\mathrm{pH}$ near 4 the wine is unprotected and many spoilage microorganisms can grow even in absence of residual sugars and high alcoholic degree. Molecular $\mathrm{SO}_{2}$ levels at $\mathrm{pH} 4$ are very low $(<0.5 \mathrm{mg} / \mathrm{L})$ even when free $\mathrm{SO}_{2}$ concentration can be higher than $50 \mathrm{mg} / \mathrm{L}$. These values are unsuitable for conflictive spoilage yeasts like Brettanomyces/Dekkera that needs $0.8 \mathrm{mg} / \mathrm{L}$ of molecular $\mathrm{SO}_{2}$ to be controlled [38]. The use of LT in mixed or sequential fermentations with S. cerevisiae when $\mathrm{pH}$ is decreased to 3.5-3.7 promotes better levels of molecular $\mathrm{SO}_{2}$ with low contents of total sulfites, making the fermentations and especially the ageing process safer.

Table 1. Acidification biotechnologies using Lachancea thermotolerans in wine fermentation suitable to be used in high $\mathrm{pH}$ musts from warm regions.

\begin{tabular}{|c|c|c|c|c|}
\hline Biotechnology & LT Fermentation Time & Initial $\mathrm{pH}$ & Final $\mathrm{pH}$ & Comments \\
\hline $\begin{array}{c}\text { Sequential fermentation } \\
\text { LT } \rightarrow \text { S. Cerevisiae } \\
\text { LT } \rightarrow \text { S. pombe }\end{array}$ & $\begin{array}{l}0-4 \text { days } \\
\text { Most of the acidification is } \\
\text { performed in the } 3 \text { first days }\end{array}$ & $3.9-4.2$ & $\begin{array}{l}\text { 3.5-3.7 depending on LT strains } \\
\text { and implantation success }\end{array}$ & $\begin{array}{c}\text { Population inoculated of } \\
\text { LT must be }>\log 6 \\
\text { CFU } / \mathrm{mL}\end{array}$ \\
\hline $\begin{array}{l}\text { Mixed fermentation } \\
\text { LT }+ \text { S. Cerevisiae } \\
\text { LT + S. pombe }\end{array}$ & $0-6$ days & $3.9-4.2$ & $\begin{array}{l}\text { 3.5-3.7 depending on LT strains } \\
\text { and implantation success }\end{array}$ & $\begin{array}{l}\text { Population inoculated of } \\
\text { LT must be }>\log 6 \text { CFU } / \mathrm{mL} \\
\text { Ratio between } \mathrm{LT}+S \text {. } \\
\text { cerevisiae (or } S \text {. pombe) } \\
\text { must be } \log 6 / \log 2 \\
\text { including wild Sacch. }\end{array}$ \\
\hline $\begin{array}{l}\text { Coinoculation LT + LAB } \\
(O . \text { oeni }) \text { and subsequent } \\
\text { inoculation of } S \text {. cerevisiae }\end{array}$ & $0-6$ days & $3.9-4.2$ & $\begin{array}{l}\text { 3.3-3.5 depending on LT strains, } \\
\text { implantation success and lactic } \\
\text { acid production by LAB }\end{array}$ & $\begin{array}{l}\text { Strong } \mathrm{pH} \text { reduction. } \\
\text { Light alcohol degree } \\
\text { reduction }\end{array}$ \\
\hline
\end{tabular}
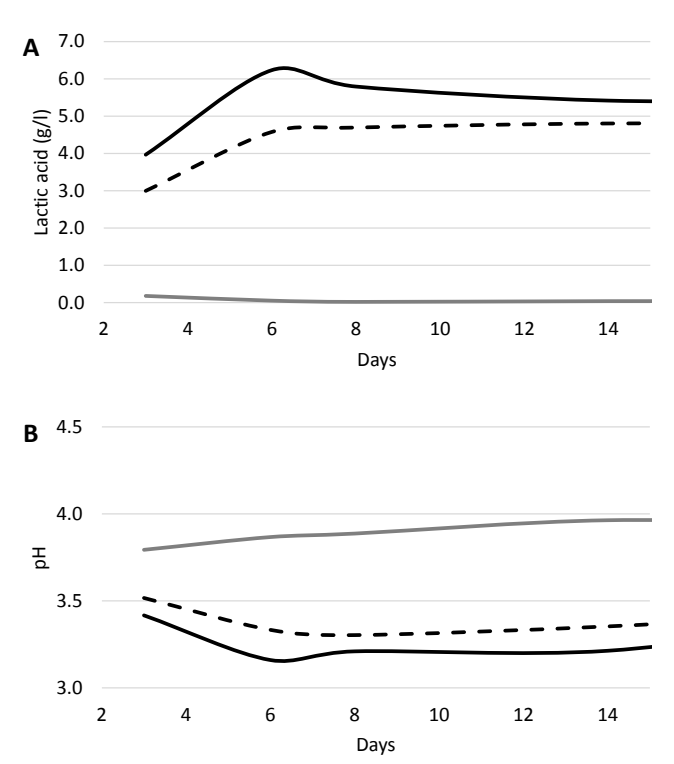

Figure 4. Lactic acid production (A) and $\mathrm{pH}(\mathbf{B})$ evolution during the fermentation of a red grape must with $240 \mathrm{~g} / \mathrm{L}$ of sugar by Lachancea thermotolerans strain L3.1 (black line), L. thermotolerans and sequentially S. cerevisiae (dashed line) and S. cerevisiae (grey line). 
LT is unable to entirely ferment a grape must as said, reaching maximum ethanol concentrations around $9 \% v / v$, even when especially selected yeasts are used. So, it is necessary to use sequential or mixed fermentations with $S$. cerevisiae $[7,12]$ or $S$. pombe $[39,40]$ to get completely dry wines without residual sugars. The use of an inoculation ratio $\log 7: \log 3 \mathrm{cfu} / \mathrm{mL}$ (LT/S. cerevisiae) is suitable to see a significant effect in $\mathrm{pH}$ reduction [12]. Suitable implantation to reach an effective acidification has also been tested according to inoculum size in mixed fermentations with S. cerevisiae [13]. However, the best results were reached in sequential inoculation after $48 \mathrm{~h}$, decreasing the $\mathrm{pH}$ values from 3.53 in S. cerevisiae control fermentation to 3.33 [13]. When the inoculation is performed after $24 \mathrm{~h}, \mathrm{pH}$ reduction is lower than 0.1 units, statistically significant, but probably without enological repercussions.

The production of lactic acid during fermentations with variable glucose contents in model media $(8,12,16 \% w / w)$ is stable and independent of sugar levels, ranging from $2.48 \pm 0.8-2.66 \pm 0.9 \mathrm{~g} / \mathrm{L}$ for LT strain L3.1 [41]. However, when the same sugar concentrations were tested in the presence of $2 \mathrm{~g} / \mathrm{L}$ of lactic acid, the production by LT was affected, ranging from $1.25 \pm 0.7 \mathrm{~g} / \mathrm{L}$ (in model media with $8 \%$ $w / w$ glucose) to $3.68 \pm 0.3 \mathrm{~g} / \mathrm{L}$ (with $16 \% w / w$ glucose). Nitrogen contents also affect the production of lactic acid by LT, being reduced below $150 \mathrm{mg} / \mathrm{L}$ of yeast assimilable nitrogen (YAN), but also at high concentration (>500 mg/L) (Figure 5). Highest lactic acid production is correlated with suitable YAN levels for yeast nutrition (150-200 mg/L) and subsequently with higher yeast populations (Figure 5).

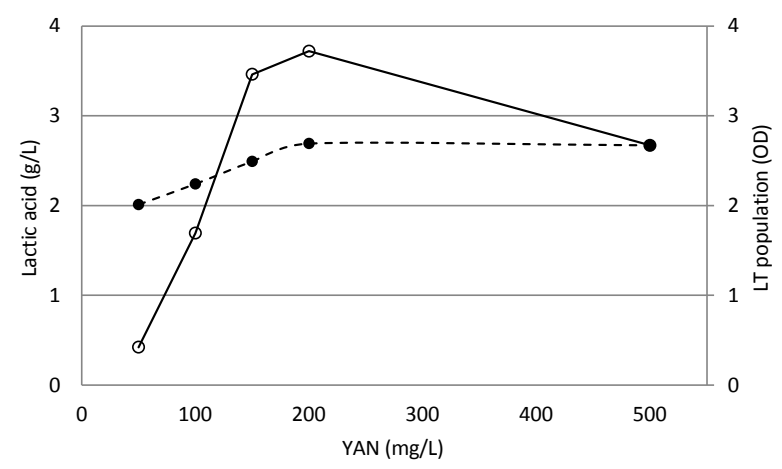

Figure 5. Lactic acid production during fermentation by L. thermotolerans strain L3.1 at variable yeast assimilable nitrogen (YAN) concentrations (black line). LT population estimated by OD (dashed line). Adapted from Hernández [41].

The use of LT fermentations together with $S$. pombe has been described as an alternative biotechnological tool to emulate malolactic fermentation (MLF) [42]. However, even when it can be similar in terms of acidification, the sensory profile reached in a typical MLF is more complex [43].

Initial evidence suggests that the use of LT is compatible with MLF [44]. However, lactic acid at high concentration $(>4 \mathrm{~g} / \mathrm{L})$, as can be produced when LT is used during fermentation, can behave as an inhibitor of lactic acid bacteria (LAB), thus hindering MLF. It is possible to use yeast-bacteria co-inoculations to facilitate the MLF by promoting the simultaneous development of alcoholic and malolactic fermentations. The use of LT-LAB co-inoculations with subsequent $S$. cerevisiae sequential fermentation (LT-LAB-SC) is quite effective to degrade malic acid and the same time reach lower $\mathrm{pH}$ values. When this biotechnology has been used at industrial level in fermentations of 1 ton of crushed grapes, the final $\mathrm{pH}$ reached 3.3 while the control only fermented by S. cerevisiae remained at $\mathrm{pH} 4$ that was the initial grape value. In this case, some acidification is produced by LT and a complementary amount of lactic acid is produced by fermentation of sugars by LAB. Both microorganisms work promoting the formation of stable acidity in natural enological conditions. Achieving these $\mathrm{pH}$ values is only possible by using ion exchange resins, but affecting strongly wine composition and quality.

Traditionally, MLF is a way to obtain microbiologically stable red wines with a better sensory profile, but it can also affect the freshness in wines of warm areas. However, the use of LT with the production of high contents of lactic acid ( $>4 \mathrm{~g} / \mathrm{L})$ because of its inhibitory effect on LAB, can be an 
approach to obtain fresh wines in warm regions protecting malic acidity but also increasing lactic acidity and with a suitable stability.

\section{Metabolic Profile and Influence on Wine Aroma and Flavor}

The use of LT in wine has been described with a low production of volatile acidity (0.3-0.5 g/L [12,16]). LT was reported as a useful biotechnological tool to decrease volatile acidity [45]. Acetaldehyde levels similarly can be diminished by using LT during fermentation [22,46]. LT has been described as a moderated producer of higher alcohols [22]. The production of ethyl acetate is quite moderate (40-60 mg/L, [13]). Sequential fermentations of LT with $S$. pombe produce similar concentrations than with $S$. cerevisiae $(40-50 \mathrm{mg} / \mathrm{L},[40])$. It is an interesting yeast to control volatile acidity produced by $S$. pombe to make full fermentations in absence of $S$. cerevisiae [39]. The production of ethyl lactate is moderate in sequential fermentations with $S$. cerevisiae $(7-8 \mathrm{mg} / \mathrm{L})$ and in mixed fermentations with $S$. pombe $(8-32 \mathrm{mg} / \mathrm{L})[39,40]$.

LT have been described as producer of $\beta$-D-glucosidase ( $\beta$ DG) [47] and carbon-sulfur lyase (CSL) [48], enzymes involved in the release of aroma compounds from must varietal precursors (Table 2). Usually non-Saccharomyces are more effective producing 3-mercaptohexan-1-ol (3MH) than 4-mercapto-4-methylpentan-2-one (4MMP) [49]. However, when LT have been used in must fermentation, significant amounts of $4 \mathrm{MMP}$ also moderate amounts of $3 \mathrm{MH}$ were released. The production of significant concentrations of 4-methyl-4-sulfanylpentan-2-one (4MSP; box-tree aroma) and 3-sulfanylhexan-1-ol (3SH; grapefruit and passion fruit hints) has also been described [48].

Table 2. Effect of Lachancea thermotolerans in wine fermentation.

\begin{tabular}{|c|c|c|c|c|}
\hline $\begin{array}{c}\text { Acidification } \mathrm{pH} \text { or Lactic } \\
\text { Acid }(\mathrm{g} / \mathrm{L})\end{array}$ & $\begin{array}{c}\text { Fermentative } \\
\text { Power (Ethanol } \\
\% v / v)\end{array}$ & $\begin{array}{c}\text { Aroma, Flavor, } \\
\text { Polysaccharides and } \\
\text { Color }\end{array}$ & Molecules & Reference \\
\hline $3.5 \rightarrow 3.2 ; 5.1 \mathrm{~g} / \mathrm{L}$ lactic acid & 9 & \multirow{5}{*}{ Acidity } & \multirow{5}{*}{ Lactic acid } & [16] \\
\hline $3.2 \rightarrow 2.9$ in coinoculation & $4-8$ & & & [12] \\
\hline $\begin{array}{c}3.53 \rightarrow 3.33 \text { sequential } 48 \mathrm{~h} \\
0.1 \text { units reduction } \\
\text { sequential } 24 \mathrm{~h}\end{array}$ & 10.5 & & & [13] \\
\hline $1-16.6 \mathrm{~g} / \mathrm{L}$ & & & & [28] \\
\hline \multirow[t]{7}{*}{$1.2-2.6 \mathrm{~g} /$} & $9.5-10.4$ & & & [14] \\
\hline & & Esters & $\begin{array}{l}\text { 2-phenylethanol, phenethyl } \\
\text { propionate, ethyl salicylate, } \\
\text { methyl salicylate, } \\
\text { 3-methylthio-1-propanol }\end{array}$ & [50] \\
\hline & & $\begin{array}{l}\text { Enhanced formation } \\
\text { of terpenes \& Thiols }\end{array}$ & $\begin{array}{l}\text { Nerol, terpinen-4-ol 4MSP } \\
\text { \& 3SH }\end{array}$ & [48] \\
\hline & & $\begin{array}{l}\beta \text {-D-glucosidase } \\
\text { Carbon-sulfur lyase }\end{array}$ & Free terpenes and thiols & {$[47,48]$} \\
\hline & 7.7 & $\begin{array}{l}\text { Polysaccharides/ } \\
\text { mannoproteins }\end{array}$ & $\mathrm{N}$-acetyl hexosamines & [51] \\
\hline & & Polyalcohols & Glycerol & {$[12,16]$} \\
\hline & & Polymeric pigments & $\begin{array}{l}\text { malvidin-3-glucoside-ethyl- } \\
\text { catechin dimer }\end{array}$ & [40] \\
\hline
\end{tabular}

The use of LT in the fermentation of Syrah and Sauvignon blanc musts increased the formation of 2-phenylethanol, phenethyl propionate, ethyl salicylate, methyl salicylate, 3-methylthio-1-propanol [50]. The contents of terpenes nerol and terpinen-4-ol were also positively affected (Table 2). LT general effect in aroma profile is the production of several acetate esters and certain terpenes [52]. 
One of the most highlighted roles of L. thermotolerans is the production of glycerol during wine fermentation. This increase in glycerol is observed during spontaneous fermentation $[12,53,54]$, and sequential inoculations between $L$. thermotolerans and S. cerevisiae $[12,13,16]$. However, in the case of sequential inoculations the main advantage is that glycerol is generated with a decreased volatile acidity and acetic acid concentration [12,55]. The production of glycerol is also highly related to the fermentation temperature [13] and it increases with oxygenation [56]. Generally speaking, the extent of influence that $L$. thermotolerans can exert on a given fermentation is relative to the amount of time it spends alone in contact with the grape must $[13,16]$. Glycerol, the next major yeast metabolite after ethanol, is associated with the smoothness (mouth-feel), sweetness and complexity in wines [57]. However, the sensory impact of glycerol is also intimately related to the grape variety and wine style [58].

Other relevant application of LT is the sensory improvement of typical regional wines [59,60]. Recently, it has been observed the key contribution of microbioma influence in terroir finger print of regional wines [61].

\section{Effect on Wine Color}

Yeasts can affect wine color by $\mathrm{pH}$ reduction [62], favoring the formation of stable pigments such as pyranoanthocyanins [63-66] or polymeric pigments [40,67], reducing the adsorption of grape anthocyanins in cell walls $[66,68,69]$, or protecting the anthocyanins from oxidative damage by releasing reductive compounds like glutathione during fermentation and ageing on lees [62].

As for acidification, some yeasts are able to reduce wine $\mathrm{pH}$ during fermentation through the release or transformation of certain organic acids. Color intensity of anthocyanins is $\mathrm{pH}$ dependent. The production of lactic acid by LT during fermentation can affect strongly the acidity with reductions of $0.3-0.5 \mathrm{pH}$ units in some cases, so it can affect wine color in a significant way. Moreover, as the lactic acid is stable during ageing, this effect can be permanent in wine. Additionally, it should be considered that acidity also helps to protect wine color by producing higher levels of molecular $\mathrm{SO}_{2}$.

The effect of the formation of pyranoanthocyanins like vitisins during fermentation is promoted by the release of the precursors: Pyruvic acid for vitisin A and acetaldehyde for vitisin B. The correlation between the excretion of these metabolites by $S$. cerevisiae strains and the subsequent condensation with malvidin-3-O-glucoside has been previously reported [63]. Not significant effects on the formation of vitisins have been observed when LT has been used in sequential fermentations with S. cerevisiae $[39,40]$. Some improvements can be seen when LT is used sequentially with S. pombe, but this is due to the contribution of this last yeast. The selection of appropriate strains can increase the formation of vitisins during fermentation, but it does not seem that LT is a good promoter for fermentative formation of vitisins. Similar results have been published for the formation of vinylphenolic pyranoanthocyanins $[39,40]$, so probably most of the LT strains do not express hydroxycinnamate decarboxylase activity. Concerning the formation of polymeric pigments, sequential fermentations of LT with S. cerevisiae and especially with $S$. pombe favors the formation of malvidin-3-glucoside-ethyl-catechin dimer [40] (Table 2).

The absorption of anthocyanins in yeast cell walls can be between 3 and $6 \%$ of total content in wines [69]. Adsorption is strain dependent in S. cerevisiae [68] but also variable among non-Saccharomyces species [62]. Compared with other species, LT has shown a medium-high adsorption capacity.

\section{Special Wines}

The use of LT could be also interesting in special sweet wines to better balance sweetness and acidity. The fermentative production of lactic acid by LT can help to make the strongly sweet wines like ice wines more pleasant, increasing the freshness when the grape acidity levels are unsuitable. Using LT, it could be possible to ferment at around $8-10 \% v / v$ of ethanol, remaining natural residual sugars together with a well-balanced acidity. 
The quality of natural sparkling wines with second fermentation in bottle is strongly dependent on freshness, and therefore, in acidity. When the base wine is produced in warm areas frequently it lacks of enough acidity what affects sensory quality in mouth, but also the stability during second fermentation and ageing. The use of LT in the production of base wines is an interesting biotechnological tool to provide them of enough stable acidity to make safer fermentations in bottle, but also reaching better sensory profiles.

The complementary use of fructophilic non-Saccharomyces yeasts, such as Candida zemplinina [70], helps to increase sugar consumption enhancing at the same time flavor, what can be useful in some wine types. C. zemplinina also improve mouthfeel and roundness due to its high production of glycerol [70].

\section{Conclusions}

LT is a really interesting non-Saccharomyces yeast species to improve the quality of wine fermentation. The natural acidification by production of stable lactic acid facilitates safer wines, less prone to spoilage, with a higher freshness and with lower levels of $\mathrm{SO}_{2}$. Also, it opens the possibility of new biotechnologies as the simultaneous co-fermentation with lactic acid bacteria reaching even lower pHs and also consuming sugars what can reduce slightly the alcohol content. It would be interesting to go deeper into the selection of LT strains to get a stronger fermenter able to surpass $10 \% v / v$ in ethanol content.

Author Contributions: A.M. Revision of the articles and writing; I.L. Revision of the articles and writing; W.T. Revision, writing and critical reading; M.A.B. Figures and molecular biology tests; C.G. Revision and ritical Reading; J.A.S.L. Critical Reading.

Funding: This research received no external funding.

Conflicts of Interest: The authors declare no conflicts of interest.

\section{References}

1. Kurtzman, C.P. Phylogenetic circumscription of Saccharomyces, Kluyveromyces and other members of the Saccharomycetaceae, and the proposal of the new genera Lachancea, Nakaseomyces, Naumovia, Vanderwaltozyma and Zygotorulaspora. FEMS Yeast Res. 2003, 4, 233-245. [CrossRef]

2. Ganter, P.F. Yeast and invertebrate associations. In Biodiversity and Ecophysiology of Yeasts; Rosa, C.A., Gabor, P., Eds.; Springer: Berlin, Germany, 2006; pp. 303-370.

3. Hranilovic, A.; Bely, M.; Masneuf-Pomarede, I.; Jiranek, V.; Albertin, W. The evolution of Lachancea thermotolerans is driven by geographical determination, anthropisation and flux between different ecosystems. PLoS ONE 2017, 12, e0184652. [CrossRef] [PubMed]

4. Combina, M.; Elía, A.; Mercado, L.; Catania, C.; Ganga, A.; Martinez, C. Dynamics of indigenous yeast populations during spontaneous fermentation of wines from Mendoza, Argentina. Int. J. Food Microbiol. 2005, 99, 237-243. [CrossRef] [PubMed]

5. Schnierda, T.; Bauer, F.F.; Divol, B.; van Rensburg, E.; Görgens, J.F. Optimization of carbon and nitrogen medium components for biomass production using non-Saccharomyces wine yeasts. Lett. Appl. Microbiol. 2014, 58, 478-485. [CrossRef] [PubMed]

6. Lachance, M.-A.; Kurtzman, C.P. Chapter 41-Lachancea Kurtzman. In The Yeasts, 5th ed.; Elsevier: New York, NY, USA, 2011; pp. 511-519. ISBN 9780444521491.

7. Ciani, M.; Beco, L.; Comitini, F. Fermentation behaviour and metabolic interactions of multistarter wine yeast fermentations. Int. J. Food Microbiol. 2006, 108, 239-245. [CrossRef] [PubMed]

8. Kemsawasd, V.; Viana, T.; Ardö, Y.; Arneborg, N. Influence of nitrogen sources on growth and fermentation performance of different wine yeast species during alcoholic fermentation. Appl. Microbiol. Biotechnol. 2015, 99, 10191-10207. [CrossRef] [PubMed]

9. Escribano, R.; González-Arenzana, L.; Garijo, P.; Berlanas, C.; López-Alfaro, I.; López, R.; Gutiérrez, A.R.; Santamaría, P. Screening of enzymatic activities within different enological non-Saccharomyces yeasts. J. Food Sci. Technol. 2017, 54, 1555-1564. [CrossRef] [PubMed] 
10. Fleet, G.H. Yeast interactions and wine flavor. Int. J. Food Microbiol. 2003, 86, 11-22. [CrossRef]

11. Kapsopoulou, K.; Kapaklis, A.; Spyropoulos, H. Growth and fermentation characteristics of a strain of the wine yeast Kluyveromyces thermotolerans isolated in Greece. World J. Microbiol. Biotechnol. 2005, 21, 1599-1602. [CrossRef]

12. Comitini, F.; Gobbi, M.; Domizio, P.; Romani, C.; Lencioni, L.; Mannazzu, I.; Ciani, M. Selected non-Saccharomyces wine yeasts in controlled multistarter fermentations with Saccharomyces cerevisiae. Food Microbiol. 2011, 28, 873-882. [CrossRef] [PubMed]

13. Gobbi, M.; Comitini, F.; Domizio, P.; Romani, C.; Lencioni, L.; Mannazzu, I.; Ciani, M. Lachancea thermotolerans and Saccharomyces cerevisiae in simultaneous and sequential co-fermentation: A strategy to enhance acidity and improve the overall quality of wine. Food Microbiol. 2013, 33, 271-281. [CrossRef] [PubMed]

14. Aponte, M.; Blaiotta, G. Potential role of yeast strains isolated from grapes in the production of Taurasi DOCG. Front. Microbiol. 2016, 7, 809. [CrossRef] [PubMed]

15. Ciani, M.; Morales, P.; Comitini, F.; Tronchoni, J.; Canonico, L.; Curiel, J.A.; Oro, L.; Rodrigues Alda, J.; Gonzalez, R. Non-conventional yeast species for lowering ethanol content of wines. Front. Microbiol. 2016, 7, 642. [CrossRef] [PubMed]

16. Kapsopoulou, K.; Mourtzini, A.; Anthoulas, M.; Nerantzis, E. Biological acidification during grape must fermentation using mixed cultures of Kluyveromyces thermotolerans and Saccharomyces cerevisiae. World J. Microbiol. Biotechnol. 2007, 23, 735-739. [CrossRef]

17. Mills, D.A.; Johannsen, E.A.; Cocolin, L. Yeast diversity and persistence in Botrytis-affected wine fermentations. Appl. Environ. Microbiol. 2002, 68, 4884-4893. [CrossRef] [PubMed]

18. Holm Hansen, E.; Nissen, P.; Sommer, P.; Nielsen, J.C.; Arneborg, N. The effect of oxygen on the survival of non-Saccharomyces yeasts during mixed culture fermentations of grape juice with Saccharomyces cerevisiae. J. Appl. Microbiol. 2001, 91, 541-547. [CrossRef] [PubMed]

19. Costa, A.; Barata, A.; Malfeito-Ferreira, M.; Loureiro, V. Evaluation of the inhibitory effect of dimethyl dicarbonate (DMDC) against wine microorganisms. Food Microbiol. 2008, 25, 422-427. [CrossRef] [PubMed]

20. CHR-Hansen. CONCERTO ${ }^{\mathrm{TM}}$. Available online: https://www.chr-hansen.com/en/food-cultures-andenzymes/wine/cards / product-cards/concerto?countryreset=1 (accessed on 30 June 2018).

21. Petruzzi, L.; Capozzi, V.; Berbegal, C.; Corbo, M.R.; Bevilacqua, A.; Spano, G.; Sinigaglia, M. Microbial resources and enological significance: Opportunities and benefits. Front. Microbiol. 2017, 8, 995. [CrossRef] [PubMed]

22. Balikci, E.K.; Tanguler, H.; Jolly, N.P.; Erten, H. Influence of Lachancea thermotolerans on cv. Emir wine fermentation. Yeast 2016, 33, 313-321. [CrossRef] [PubMed]

23. García, M.; Esteve-Zarzoso, B.; Crespo, J.; Cabellos, J.M.; Arroyo, T. Yeast monitoring of wine mixed or sequential fermentations made by native strains from D.O. "Vinos de Madrid" using Real-Time Quantitative PCR. Front. Microbiol. 2017, 8, 2520. [CrossRef] [PubMed]

24. Fiori, S.; Urgeghe, P.P.; Hammami, W.; Razzu, S.; Jaoua, S.; Migheli, Q. Biocontrol activity of four non- and low-fermenting yeast strains against Aspergillus carbonarius and their ability to remove ochratoxin A from grape juice. Int. J. Food Microbiol. 2014, 189, 45-50. [CrossRef] [PubMed]

25. Nally, M.C.; Ponsone, M.L.; Pesce, V.M.; Toro, M.E.; Vazquez, F.; Chulze, S. Evaluation of behaviour of Lachancea thermotolerans biocontrol agents on grape fermentations. Lett. Appl. Microbiol. 2018, 67, 89-96. [CrossRef] [PubMed]

26. Loira, I.; Morata, A.; Bañuelos, M.A.; Suárez-Lepe, J.A. Isolation, selection and identification techniques for non-Saccharomyces yeasts of oenological interest. In Biotechnological Progress and Beverage Consumption; Beverage Series; Academic Press-Elsevier: Cambridge, MA, USA, 2018; Volume 19, in press.

27. Prakitchaiwattana, C.J.; Fleet, G.H.; Heard, G.M. Application and evaluation of denaturing gradient gel electrophoresis to analyse the yeast ecology of wine grapes. FEMS Yeast Res. 2004, 4, 865-877. [CrossRef] [PubMed]

28. Banilas, G.; Sgouros, G.; Nisiotou, A. Development of microsatellite markers for Lachancea thermotolerans typing and population structure of wine-associated isolates. Microbiol. Res. 2016, 193, 1-10. [CrossRef] [PubMed]

29. Kurtzman, C.P.; Robnett, C.J. Identification and phylogeny of ascomycetous yeasts from analysis of nuclear large subunit (26S) ribosomal DNA partial sequences. Antonie Van Leeuwenhoek 1998, 73, 331-371. [CrossRef] [PubMed] 
30. Lopandic, K.; Tiefenbrunner, W.; Gangl, H.; Mandl, K.; Berger, S.; Leitner, G.; Abd-Ellah, G.A.; Querol, A.; Gardner, R.C.; Sterflinger, K.; et al. Molecular profiling of yeasts isolated during spontaneous fermentations of Austrian wines. FEMS Yeast Res. 2008, 8, 1063-1075. [CrossRef] [PubMed]

31. Baleiras Couto, M.M.; Reizinho, R.G.; Duarte, F.L. Partial $26 \mathrm{~S}$ rDNA restriction analysis as a tool to characterise non-Saccharomyces yeasts present during red wine fermentations. Int. J. Food Microbiol. 2005, 102, 49-56. [CrossRef] [PubMed]

32. Zara, G.; Ciani, M.; Domizio, P.; Zara, S.; Budroni, M.; Carboni, A.; Mannazzu, I. A culture-independent PCR-based method for the detection of Lachancea thermotolerans in wine. Ann. Microbiol. 2014, 64, 403-406. [CrossRef]

33. Mora, J.; Barbas, J.I.; Mulet, A. Growth of yeast species during the fermentation of musts Inoculated with Kluyveromyces thermotolerans and Saccharomyces cerevisiae. Am. J. Enol. Vitic. 1990, 41, 156-159.

34. Jolly, N.P.; Varela, C.; Pretorius, I.S. Not your ordinary yeast: Non-Saccharomyces yeasts in wine production uncovered. FEMS Yeast Res. 2014, 14, 215-237. [CrossRef] [PubMed]

35. Domizio, P.; House, J.F.; Joseph, C.M.L.; Bisson, L.F.; Bamforth, C.W. Lachancea thermotolerans as an alternative yeast for the production of beer. J. Inst. Brew. 2016, 122, 599-604. [CrossRef]

36. Callejo, M.J.; González, C.; Morata, A. Use of non-Saccharomyces yeasts in bottle fermentation of aged beers. In Brewing Technology; Kanauchi, M., Ed.; IntechOpen: London, UK, 2017; Available online: https:/ / www.intechopen.com/books/brewing-technology/use-of-non-saccharomyces-yeasts-inbottle-fermentation-of-aged-beers (accessed on 30 June 2018).

37. Osburn, K.; Amaral, J.; Metcalf, S.R.; Nickens, D.M.; Rogers, C.M.; Sausen, C.; Caputo, R.; Miller, J.; Li, H.; Tennessen, J.M.; et al. A novel bacteria-free method for sour beer production. Food Microbiol. 2018, 70, 76-84. [CrossRef] [PubMed]

38. Suárez, R.; Suárez-Lepe, J.A.; Morata, A.; Calderón, F. The production of ethylphenols in wine by yeasts of the genera Brettanomyces and Dekkera: A review. Food Chem. 2007, 102, 10-21. [CrossRef]

39. Del Fresno, J.M.; Morata, A.; Loira, I.; Bañuelos, M.A.; Escott, C.; Benito, S.; González Chamorro, C.; Suárez-Lepe, J.A. Use of non-Saccharomyces in single-culture, mixed and sequential fermentation to improve red wine quality. Eur. Food Res. Technol. 2017, 243, 2175-2185. [CrossRef]

40. Escott, C.; Del Fresno, J.M.; Loira, I.; Morata, A.; Tesfaye, W.; González, M.C.; Suárez-Lepe, J.A. Formation of polymeric pigments in red wines through sequential fermentation of flavanol-enriched musts with non-Saccharomyces yeasts. Food Chem. 2018, 239, 975-983. [CrossRef] [PubMed]

41. Hernández, P. Use of Lachancea thermotolerans to Improve pH in Red Wines. Effect of the Coinoculation with Oenococcus oeni. Master's Thesis, Universidad Politécnica de Madrid, Madrid, Spain, 2018.

42. Benito, Á.; Calderón, F.; Palomero, F.; Benito, S. Combine use of selected Schizosaccharomyces pombe and Lachancea thermotolerans yeast strains as an alternative to the traditional malolactic fermentation in red wine production. Molecules 2015, 20, 9510-9523. [CrossRef] [PubMed]

43. Lerm, E.; Engelbrecht, L.; du Toit, M. Malolactic Fermentation: The ABC's of MLF. S. Afr. J. Enol. Vitic. 2010, 31, 186-212. [CrossRef]

44. Du Plessis, H.W.; du Toit, M.; Hoff, J.W.; Hart, R.S.; Ndimba, B.K.; Jolly, N.P. Characterisation of non-Saccharomyces yeasts using different methodologies and evaluation of their compatibility with malolactic fermentation. S. Afr. J. Enol. Vitic. 2017, 38, 46-63. [CrossRef]

45. Vilela-Moura, A.; Schuller, D.; Mendes-Faia, A.; Côrte-Real, M. Reduction of volatile acidity of wines by selected yeast strains. Appl. Microbiol. Biotechnol. 2008, 80, 881-890. [CrossRef] [PubMed]

46. Ciani, M.; Comitini, F. Non-Saccharomyces wine yeasts have a promising role in biotechnological approaches to winemaking. Ann. Microbiol. 2011, 61, 25-32. [CrossRef]

47. Rosi, I.; Vinella, M.; Domizio, P. Characterization of $\beta$-glucosidase activity in yeasts of oenological origin. J. Appl. Bacteriol. 1994, 77, 519-527. [CrossRef] [PubMed]

48. Zott, K.; Thibon, C.; Bely, M.; Lonvaud-Funel, A.; Dubourdieu, D.; Masneuf-Pomarede, I. The grape must non-Saccharomyces microbial community: Impact on volatile thiol release. Int. J. Food Microbiol. 2011, 151, 210-215. [CrossRef] [PubMed]

49. Padilla, B.; Gil, J.V.; Manzanares, P. Past and future of non-Saccharomyces yeasts: From spoilage microorganisms to biotechnological tools for improving wine aroma complexity. Front. Microbiol. 2016, 7, 411. [CrossRef] [PubMed] 
50. Beckner Whitener, M.E.; Carlina, S.; Jacobson, D.; Weighill, D.; Divol, B.; Conterno, L.; Du Toit, M.; Vrhovsek, U. Early fermentation volatile metabolite profile of non-Saccharomyces yeasts in red and white grape must: A targeted approach. LWT Food Sci. Technol. 2015, 64, 412-422. [CrossRef]

51. Domizio, P.; Liu, Y.; Bisson, L.F.; Barile, D. Use of non-Saccharomyces wine yeasts as novel sources of mannoproteins in wine. Food Microbiol. 2014, 43, 5-15. [CrossRef] [PubMed]

52. Beckner Whitener, M.E.; Stanstrup, J.; Panzeri, V.; Carlin, S.; Divol, B.; Du Toit, M.; Vrhovsek, U. Untangling the wine metabolome by combining untargeted SPME-GCxGC-TOF-MS and sensory analysis to profile Sauvignon blanc co-fermented with seven different yeasts. Metabolomics 2016, 12, 53. [CrossRef]

53. Romano, P.; Suzzi, G.; Comi, G.; Zironi, R.; Maifreni, M. Glycerol and other fermentation products of apiculate wine yeasts. J. Appl. Microbiol. 1997, 82, 615-618. [CrossRef] [PubMed]

54. Henick-Kling, T.; Edinger, W.; Daniel, P.; Monk, P. Selective effects of sulfur dioxide and yeast starter culture addition on indigenous yeast populations and sensory characteristics of wine. J. Appl. Microbiol. 1998, 84, 865-876. [CrossRef]

55. Domizio, P.; Romani, C.; Lencioni, L.; Comitini, F.; Gobbi, M.; Mannazzu, I.; Ciani, M. Outlining a future for non-Saccharomyces yeasts: Selection of putative spoilage wine strains to be used in association with Saccharomyces cerevisiae for grape juice fermentation. Int. J. Food Microbiol. 2011, 147, 170-180. [CrossRef] [PubMed]

56. Shekhawat, K.; Porter, T.J.; Bauer, F.F.; Setati, M.E. Employing oxygen pulses to modulate Lachancea thermotolerans-Saccharomyces cerevisiae Chardonnay fermentations. Ann. Microbiol. 2018, 68, 93-102. [CrossRef]

57. Ciani, M.; Maccarelli, F. Oenological properties of non-Saccharomyces yeasts associated with wine-making. World J. Microbiol. Biotechnol. 1998, 14, 199-203. [CrossRef]

58. Nieuwoudt, H.H.; Prior, B.A.; Pretorius, I.S.; Bauer, F.F. Glycerol in South African table wines: An assessment of its relationship to wine quality. S. Afr. J. Enol. Vitic. 2002, 23, 22-30. [CrossRef]

59. Capozzi, V.; Garofalo, C.; Chiriatti, M.A.; Grieco, F.; Spano, G. Microbial terroir and food innovation: The case of yeast biodiversity in wine. Microbiol. Res. 2015, 181, 75-83. [CrossRef] [PubMed]

60. Pinto, C.; Pinho, D.; Cardoso, R.; Custódio, V.; Fernandes, J.; Sousa, S.; Pinheiro, M.; Egas, C.; Gomes, A.C. Wine fermentation microbiome: A landscape from different Portuguese wine appellations. Front. Microbiol. 2015, 6, 905. [CrossRef] [PubMed]

61. Bokulich, N.A.; Collins, T.S.; Masarweh, C.; Allen, G.; Heymann, H.; Ebeler, S.E.; Mills, D.A. Associations among wine grape microbiome, metabolome, and fermentation behavior suggest microbial contribution to regional wine characteristics. mBio 2016, 7, e00631-16. [CrossRef] [PubMed]

62. Morata, A.; Loira, I.; Suárez Lepe, J.A. Influence of Yeasts in Wine Colour. In Grape and Wine Biotechnology; Morata, A., Loira, I., Eds.; IntechOpen: London, UK, 2016; pp. 285-305. Available online: https:/ / www. intechopen.com/books/grape-and-wine-biotechnology/influence-of-yeasts-in-wine-colour (accessed on 30 June 2018).

63. Morata, A.; Gómez-Cordovés, M.C.; Colomo, B.; Suárez, J.A. Pyruvic acid and acetaldehyde production by different strains of Saccharomyces cerevisiae: Relationship with vitisin A and B formation in red wines. J. Agric. Food Chem. 2003, 51, 6475-6481. [CrossRef] [PubMed]

64. Morata, A.; Gómez-Cordovés, M.C.; Calderón, F.; Suárez, J.A. Effects of pH, temperature and $\mathrm{SO}_{2}$ on the formation of pyranoanthocyanins during red wine fermentation with two species of Saccharomyces. Int. J. Food Microbiol. 2006, 106, 123-129. [CrossRef] [PubMed]

65. Morata, A.; González, C.; Suárez-Lepe, J.A. Formation of vinylphenolic pyranoanthocyanins by selected yeasts fermenting red grape musts supplemented with hydroxycinnamic acids. Int. J. Food Microbiol. 2007, 116, 144-152. [CrossRef] [PubMed]

66. Suárez-Lepe, J.A.; Morata, A. New trends in yeast selection for winemaking. Trends Food Sci. Technol. 2012, 23, 39-50. [CrossRef]

67. Escott, C.; Morata, A.; Loira, I.; Tesfaye, W.; Suarez-Lepe, J.A. Characterization of polymeric pigments and pyranoanthocyanins formed in microfermentations of non-Saccharomyces yeasts. J. Appl. Microbiol. 2016, 121, 1346-1356. [CrossRef] [PubMed]

68. Morata, A.; Gómez-Cordovés, M.C.; Suberviola, J.; Bartolomé, B.; Colomo, B.; Suárez, J.A. Adsorption of anthocyanins by yeast cell walls during the fermentation of red wines. J. Agric. Food Chem. 2003, 51, 4084-4088. [CrossRef] [PubMed] 
69. Morata, A.; Gómez-Cordovés, M.C.; Colomo, B.; Suárez, J.A. Cell wall anthocyanin adsorption by different Sacharomyces strains during the fermentation of Vitis vinifera L. cv Graciano grapes. Eur. Food Res. Technol. 2005, 220, 341-346. [CrossRef]

70. Magyar, I.; Tóth, T. Comparative evaluation of some oenological properties in wine strains of Candida stellata, Candida zemplinina, Saccharomyces uvarum and Saccharomyces cerevisiae. Food Microbiol. 2011, 28, 94-100. [CrossRef] [PubMed]

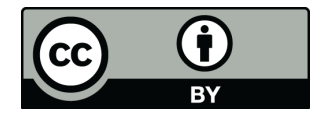

(C) 2018 by the authors. Licensee MDPI, Basel, Switzerland. This article is an open access article distributed under the terms and conditions of the Creative Commons Attribution (CC BY) license (http://creativecommons.org/licenses/by/4.0/). 